\title{
The Relationship between Exercising of Shareholders' Rights and the Performance of Firms listed at the Nairobi Securities Exchange
}

\author{
Dr. Edward Kandiru Maina
}

School of Business, Jomo Kenyatta University of Agriculture and Technology

\begin{abstract}
The continued decline in performance of firms listed in the Nairobi Securities Exchange (NSE) has lately become a source of concern to both the country's policy makers and researchers. Already, reports from the Kenyan government reveal that the decline in performance is becoming an impediment to the country's realization of Vision 2030 as the dwindling performance is leading to lower economic development and loss of jobs. This study examines the relationship between exercising of shareholders' rights and the performance of firms listed in the NSE for the period 2011-2015. The study is anchored on the shareholder theory. The study population comprises all 60 companies listed in NSE in the stated period. The study uses descriptive research and correlational research designs. Both primary and secondary data are obtained from the 60 Chief Executive Officers of the corporations or their representatives. Descriptive statistics (mean and standard deviation) and inferential statistics (Pearson correlation and multiple regression) are used to analyze the data. The study finds that there is a statistically significant relationship between shareholders exercising their rights and performance of firms listed at the Nairobi Securities Exchange. The hypothesis that shareholders exercising their rights has no significant relationship with performance of firms listed at the NSE $(\mathrm{p}<0.001)$ is rejected. Finally, results vindicate the shareholder theory.
\end{abstract}

Key words: Corporate governance, Shareholders' rights, Firm performance, Nairobi Securities Exchange

\subsection{Introduction}

The general decline of market price of shares of companies listed in the Nairobi Securities Exchange (NSE) between the years 2007-2013 (CMA, 2013) has stimulated policy research focusing on corporate governance and performance of firms listed at the NSE (Kobuthi, K'Obonyo, \& Ogutu, 2018; Mukabwa, 2016; Wanyama \& Olweny, 2013; K'Obonyo, Ongore \& Ogutu, 2011), with an overriding theme being the continued poor performance of the bourse and the inability of the existing corporate governance structures to explain recent corporate failures.

This is notwithstanding that since the NSE opened its doors to foreign investors in 1995 the Kenyan government has made several reforms aimed at attracting foreign investment via the bourse. Most significant was the NSE support of a code of best practice issued by the Centre for Corporate Governance with the objective of strengthening corporate governance practices of public listed companies in Kenya in line with international corporate governance practices (Ngugi, 2003). Although the NSE was of the view that good corporate governance practices ought to be nurtured and encouraged to evolve, it was persuaded that directors of public listed companies needed to embrace good corporate governance practices as part of their obligations to continue listing (Berzins, 2008). Thereafter the NSE also demanded directors of all listed companies make a statement indicating whether their firms were complying with the guidelines prescribed under the Capital Markets Securities Regulations (2002) starting with the financial year ending 2002 (CMA, 2013).

The government too was enthusiastic that the NSE had taken up the code and embraced the regulations more so because the NSE had assumed its rightful position as an important player in the Kenyan economy - 
especially in the privatization of state-owned enterprises. But recent statistics from the World Bank (2014) and NSE (2015) show that the guidelines that public listed companies are supposed to adhere may not of necessity guarantee performance. A perusal of the performance of the market in 2015 indicates that the NSE Share Index fell from 5117 to 3994 points (a decline of 22\%) amounting to a loss of at least Ksh. 300 billion worth of investment in one year alone (NSE, 2015). Notable cases of poor performances included Kenya Airways, which slid into the loss territory for the first time after thirteen years of profitability due to questionable corporate governance practices (Nderu, 2013); Uchumi Supermarkets which made a loss of Ksh. 3.2 billion in 2015; the National Bank of Kenya which made a loss of over Ksh. 1 billion; and Mumias Sugar which made a loss of Ksh. 2.26 billion (Omondi, 2015). Similarly, CMC whose stocks had been suspended in 2011 was finally de-listed in 2015 due to continued poor performance that was attributed to lack of adherence to best corporate governance practices.

There is no doubt that the decline in performance of the NSE has become a major hindrance in the realization of Vision 2030 in terms of lower economic development and loss of jobs in Kenya (RoK, 2014). The trend has occasioned debate for the last one decade regarding the effectiveness of internal corporate governance mechanisms of public listed companies like boards, managements' composition and boards operations. A number of studies have sought to unravel the problems that bedevil the corporate governance and performance of firms listed in the NSE (Wanyama \& Olweny, 2013; Barako \& Tower, 2007; K'Obonyo, Ongore \& Ogutu, 2011; and Ongore, 2008), but their efforts have been limited either to a few sectors of the economy, limited number of firms, or limited duration, hence the need to fill the gap. This paper reports the findings of how the rights of shareholders impact the performance of all firms spread across all sectors of the economy listed in the NSE. It is part of a completed PhD study that tested the impact of all the five corporate governance variables, as per OECD (1999) guidelines, on the performance of public listed companies in the NSE.

\subsection{Literature Review}

\subsection{Theoretical Foundations}

Studies that have attempted to explain how the rights of shareholders impact on the performance of listed companies have either relied on the stakeholder model or the stewardship model (Maher \& Andersson, 1999). However the stakeholder model has been criticized because managers or directors hostile to reforms have often cited "stakeholder" reasons to justify poor company performance (Maher \& Andersson, 1999). But firm owners have to hire managers because they need their specialised human capital to run the firm and to generate returns on their investments. As such the stewardship theory makes the assumption that managers are pro-organization and collectivistic in achieving higher utility by serving an organization than working to satisfy their goals (Tipuric, 2008). The theory regards managers as trusted stewards to act in the best interest of owners (Donaldson \& Davis, 1991) considering that their utilities get maximized whenever a firm succeeds and the wealth of the shareholders is maximized (Davis et al., 1997). In this case, the focus of stewardship theory is therefore a facilitating and empowering structure rather than a monitoring and controlling one (Davis, 1997). The theory takes cognizance of the fact that regardless of the position held by an individual, they hold it for the sole purpose of ensuring that they deliver on their mandate. However, recent studies on the theory have critiqued how policy makers can develop reforms that do not disenfranchise majority shareholders while at the same time protect the interests of minority shareholders (Maher \& Andersson, 1999).

\subsection{The Rights of Shareholders}

Miles (2006) observes that shareholders have many legal rights to a firm albeit that some of the rights are more significant than others and consequently deserve more protection in law (Miwa, 2006; Velasca, 2004). Velasca (2004) lists four types of shareholders rights: Economic rights, control rights, information rights and litigation rights and which jointly translate into good financial performance of a firm depending on how an individual firm implements them.

Velasca (2004) observes that shareholders claim economic rights because they invest in corporations primarily for economic gain. Haller (2003) underscores that shareholders can profit from a corporation by receipts of dividends or by selling shares; but Haller however observes that shareholders are only legally entitled to dividends as they are declared by the board of directors, as the board is never under any 
obligation to declare dividends as it has the choice to reinvest the profits of a company rather than distribute the incomes, if circumstances demand so. However, shareholders can financially benefit by selling their shares whenever a corporations declares profits and shares show movements (Miles, 2006) as listed companies exist for free transferability of shares.

Shareholders also have control rights of a firm and systems of corporate governance can be distinguished according to the degree of ownership and control and the identity of controlling shareholders (Maher \& Andersson, 1999). Some systems are characterised by wide dispersed ownership but others tend to be characterized by concentrated ownership or control (Maher \& Andersson, 1999; Miwa, 2006). In companies characterized by wide dispersed ownership corporate governance the basic conflict of interest is between strong managers and widely-dispersed weak shareholders (Maher \& Andersson, 1999; Miwa, 2006), whereas in companies characterized by concentrated ownership the basic conflict is between controlling shareholders (or blockholders) and weak minority shareholders (Maher \& Andersson, 1999). In such a situation individual shareholders are generally not interested in or at least not capable of exercising their control rights (Gardiner, 2006).

Bebchuk (2006) observes that shareholders have the tendency of not attending shareholders meetings but rather prefer to exercise their rights to vote through proxy means a method that is usually stacked against them. Velasco (2006) notes that the situation can get ugly if incumbent directors were permitted to use corporate funds to solicit proxies for their own re-election as ordinary shareholders would not afford such a proxy contest. But although shareholders face many obstacles in exercising their right to elect directors, they are the only ones who can elect directors. The right to elect directors becomes quite meaningful when shareholder dissatisfaction with existing management grows as it becomes easier for someone to wage a proxy contest to convince shareholders to vote against the incumbent directors, and other fundamental matters like the approval of mergers and acquisitions.

Shareholders also exercise their rights by gaining access to information. Bainbridge (2006) observes that shareholders in many countries have no general rights to information as they only have the rights to inspect corporations' books and records, which may not have a significant impact in shaping a firm's financial performance given that shareholders do not bear substantial burden of demonstrating a proper purpose. They also are only entitled to review only basic documents such as the articles of association, memorandum of association, minutes of board meetings and a list of shareholders record.

Finally, the shareholders right to litigation, that is, the ability to seek enforcement or redress for breach of management of fiduciary duties to the corporation and its shareholders, may affect a firm's financial performance in different ways (Strine, 2006). Shareholder litigation refers to all civil actions brought by shareholders against wrongdoings to ensure compensation of shareholders for infringements of their rights or any losses suffered as a result of negligent behaviour the company and its directors and by extension by third parties. The shareholders actions mainly revolve around shareholder direct actions, shareholder derivative actions and shareholders class actions. The threat of shareholder litigation mitigates concern over the moral hazard problem and might keep managers focused on innovative activities (Acharya et al, 2014).

\subsection{The Performance of a Firm}

Researchers have come out with several definitions of firm performance which vary according to the emphasis of the aspects being studied. Coulter \& Robbins (2005) define the performance of a firm as the accumulated end results of all the organization's work processes and activities. Obiwuru et al. (2011) define organizational performance to be the ability of an organization to attain the set objectives like quality products, high profits, desirable financial results, survival and large market share. Wheelen et al. (2007) describe performance as the end result of an activity, and the measures selected to assess performance depend on the organizational unit to be appraised and the desired objectives.

There are different ways of measuring organizational performance but three primary outcomes are the most analyzed: financial performance, market performance and stakeholder value performance. Financial performance measures firm performance according to its balance sheet and income statements. Taylor and Taylor (2013) describe several ratios that are generally used to measure financial performance. These are liquidity ratios, long term solvency ratios, turnover ratios, and profitability. Liquidity ratios include the 
current ratio, acid test ratio and cash ratio and are used to assess the firm's ability to pay its bills in the short run and hence their focus is on current assets and current liabilities. Long term solvency ratios also referred to as leverage ratios on the other hand are used to address a firm's long term ability to meet its obligations. They consist of total debt, times interest earned and cash coverage ratios. Asset management ratios are used to describe how efficiently or intensively a firm uses its assets to generate sales. They are the inventory turnover, receivables turnover and total turnover asset ratios. The profitability measures are the most widely used of all ratios as they measure how efficiently the firm manages its operations. They focus on the net income of a firm. They include the return on assets and return on equity ratios. Brigham and Gapenski (2008) argue that the measures of profitability can either be book value based or market value based. They contend that accounting ratios such as Tobin's Q, Return on Equity (ROE) and Return on Assets (ROA) can be used to measure the performance of a firm. Biwott (2011) and Kithii (2008) used the ratio of net income after taxes to stockholders' equity (ROE).

Lastly, the market value measures include ratios that can only be directly calculated for publicly trading companies, that is, the price earnings ratio and the market to book ratio. Mahboob (2012) maintains that for ratio analysis to be a useful measure of performance, it must go beyond calculation and interpretation of the ratios and include an analysis of how the ratios change over time and how they are interrelated.

Wheelen et al. 2007 also recommend balanced score card developed by Kaplan and Norton as another useful tool for measuring organizational performance. The tool combines financial measures with operational measures of performance. Research has found this approach to be useful because non-financial assets explain 50-80 percent of a firm's value. The balanced score card approach measures performance from four perspectives namely: financial, customer, internal business and innovation and learning perspectives (Wheelen et al. 2007). The customer perspective of the balanced score card requires that managers translate their general mission statements on customer service into specific measure that reflect factors that really matters to customers. This perspective measures such aspects as quality, cycle time, employee skills and productivity. The innovation and learning perspectives represent a firm's ability to improve, innovate and learn. This is precipitated by the fact that firms exist in an environment where the rate of markets, technologies, competition and criteria for success are constantly changing. Lastly, the financial perspective measures the extent to which the company's strategy, implementation and execution contribute to the net worth improvement (Marinova, 2004).

However, Talbot (2010) criticizes the traditional measures of financial performance - return on equity (ROE), return on asset (ROA), return on sales (ROS) and return on investment (ROI) - arguing that they do not strongly correlate to shareholder wealth especially in the public domain where citizen satisfaction with leaders is measured differently, adding that performance of an organization can be determined by measuring the outcome of the output of employees' input. Further, Carton and Hofer (2006) argue that it is critical to consider the perception of third parties in determining the performance of an organization, considering that performance is partly perceptually based on what an observer considers valuable. Of importance here would be the performance of a public entity from the service user's perspective.

\subsection{The Rights of Shareholders and the Performance of a Firm}

Two dominant views characterize the literature on relationship between corporate governance and firm performance. On one hand, Morck, Schleifer \& Vishny (1988), McConnell \& Servaes (1990) and Core \& Larcker (2002) have established that corporate governance structures influence the value of a company. On the other hand, Demsetz \& Lehn (1985) and Agarwal \& Knoeber (1996) argue that in order to maximize the value of the company corporation owners through managers have a choice on a variety of corporate governance structures to choose from, although none of the choices is correlated with corporate performance.

In regard to the relationship between rights of shareholders and the performance of a firm, available literature shows mixed conclusions. For instance, Isik and Syokan (2013) studied 164 Turkish firms listed in Istanbul Stock Exchange using panel data for the period 2003-2010. The study explored the impact of large shareholders on firm performance measured by ROA and Tobin's Q. The empirical findings based on panel data analysis suggested that large shareholders had a significant positive effect on performance of a firm. 
Onder (2003) studied the relationship between the concentration of ownership and performance of all corporations listed on ISE. The study employed ROA and Tobin's Q as dependent variables and measured ownership concentration according to the shares held by the three largest shareholders. The results indicated no significant relationship between measures of ownership concentration and ROA. There was however a quadratic relationship between ownership concentration and firm performance, measured by Tobins Q. A quadratic relationship between concentration by the largest shareholder and Tobin's Q is positive when the small shareholders own less than half of the shares of the firm.

Gonenc and Aybar (2006) also used a dataset of 185 Turkish industrial companies listed on the ISE for the period of 1992-1998 to study the effect of ownership concentration measured by the percentage of shares owned by the three largest shareholders; and managerial ownership measured by the percentage of shares owned by management on the company performance, and modelled the ownership structure as an endogenous variable. Both ROA and market-to-book ratio were used as performance variables in the analysis. They used a simultaneous equations framework to explain ownership-performance.

In Kenya, there are hardly any studies that provide a conclusive evidence of an analysis of the relationship between shareholders rights and performance of firms listed in the NSE. However, there are few studies that have examined certain aspects of corporate governance practices in relation to financial performance in certain sectors of the economy and using different sets of variables. Wanyama and Olweny (2013) examined the effect of board size, board composition, CEO duality and leverage on financial performance of listed insurance firms in Kenya. The study used ROA and ROE to measure firm performance. It used descriptive research design to study all insurance firms listed in NSE as at December 2012. The study carried out a multiple linear regression model, and established a strong relationship between the variables and the firms' financial performance. The study also found out that the separation of the role of CEO and Chair positively influenced the financial performance. However the study did not attempt to show how exercising rights by shareholders has been incorporated in Kenya's corporate sector governance.

\subsection{Firms Listed in the NSE}

The NSE was established in 1954 and as per 2017 Barclays Africa Group Financial Markets Index it was ranked fifth in Africa ahead of stronger economies like Nigeria, Ghana and Egypt in terms of depth of the market, access to foreign exchange, market transparency, tax and regulations, macro-economic opportunity and legality and enforcement. It was first registered as Nairobi Stock Exchange upon constituting as a voluntary association of stockbrokers under the Societies Act. In 1990 a trading floor and secretariat was set up at the IPS building before relocating to the Nation Centre in 1994 (Brigham \& Gapenski, 2008). According to the NSE (2017) the bourse has 64 listed firms grouped into ten sectors comprising of agricultural, automobiles and accessories, banking, commercial and services, construction and allied, energy and petroleum, insurance, investment, manufacturing and allied, and telecommunications and technology (NSE, 2017). Over the past decade, the securities exchange has witnessed numerous changes including the automating of its trading in September 2006 thus making it possible for stockbrokers to trade remotely from their offices.

The NSE is regulated by Capital Markets Authority (CMA) and aims at supporting trading, clearing settlement of equities debt derivatives and other associated instruments. It is mandated to list companies on the securities exchange and enable investors to trade in securities of companies. A number of brokers are licensed to operate in the market. The NSE opened the door to foreign investors in 1995. Foreign investment in the NSE and foreign ownership of companies is by application. However, foreign investment in the local subsidiaries of foreign-controlled companies is banned so as to encourage investment in Kenyan companies (Mahabir, 2011). Initially, the NSE offered a maximum limit of 20\% shareholding for institutions and $2.5 \%$ for individuals, but this has since been revised to $40 \%$ for institutions and $5 \%$ for individuals, although only a relatively small percentage of listed companies are available to foreigners (Ngugi, 2003). However, this has not dumped the desire for investing in local companies as the uptake for Kenyan companies' stocks have been on the rise making foreign ownership of shares at the NSE to more than a third of market value (Irungu, 2016). In fact the interest in investing in listed companies in Kenya has been phenomenal. In June 2007, for instance, when the first internet provider company (AccessKenya) listed in East Africa in NSE there was oversubscription by $363 \%$ from every category of investors. 
The Kenyan government provides important controls that are necessary in ensuring that the corporate sector succeeds. This is done through provision of an effective regulatory framework, ensuring that there is enforcement of the regulatory framework and through shareholding. The regulatory frameworks, denotes the principles, rules and policy frameworks available and how they facilitate or act as impediments towards the required standards for corporate governance among listed companies. On the other hand, enforcement of regulatory framework involves the efforts made by the government to ensure principles, rules and policy regulations are implemented. Good governance practices in the public sector and by extension the private sector has been given a boost by Chapter Six of the Kenyan Constitution 2010 because of the emphasis on ethics and integrity.

However, in spite of the existence of corporate governance regulations, recent developments in Kenya's corporate world indicate that compliance is wanting. In the recent past, Kenyans have witnessed a number of companies' experience boards' strife with the most recent case in point being CMC-Motors where transactions with related third parties were used to swindle the company's resources (Gakeri, 2013).

\subsection{Methodology}

This study was premised on positivist approach and used descriptive design to gather quantitative data from a total of 60 listed companies in the NSE as at 2015 (NSE, 2015). The 60 companies were categorised as: agricultural, commercial and services, telecommunication and technology, automobiles and accessories, banking, insurance, investment, manufacturing and allied, construction and allied and energy and petroleum.

Table 1: Listed Firms per Economic Sector

\begin{tabular}{|l|l|l|l|}
\hline S. No & Sector & Number & \% of the listed Companies \\
\hline 1. & Agricultural & 7 & 11.7 \\
\hline 2. & Commercial and services & 9 & 15 \\
\hline 3. & Telecommunication and Technology & 2 & 3.3 \\
\hline 4. & Automobiles and Accessories & 4 & 6.6 \\
\hline 5. & Banking & 10 & 16.7 \\
\hline 6. & Insurance & 6 & 10 \\
\hline 7. & Investment & 4 & 6.6 \\
\hline 8. & Manufacturing and Allied & 9 & 15 \\
\hline 9. & Construction and allied & 5 & 8.3 \\
\hline 10. & Energy and Petroleum & 5 & 6.6 \\
\hline & TOTAL & $\mathbf{6 0}$ & $\mathbf{1 0 0 \%}$ \\
\hline
\end{tabular}

Source: Nairobi Securities Exchange: Handbook 2015

The study used purposive sampling to collect data from the Chief Executive Officers (CEO) of the selected firms. The CEOs or their representatives were asked to give insights about corporate governance practices in their firms. Primary data was collected using a five-point Likert type scale questionnaire with each respondent asked to respond to the same set of questions in a pre-determined order. Secondary data was collected from the CMA and NSE in the form of financial statements of listed companies from the year 2011 to 2015. A reliability test was undertaken to ensure that the research instrument possesd internal consistency over time (Balta, 2008). Three validity tests: face validity, content validity and construct validity were also carried out. Descriptive analysis was used to examine the relationships between the sub-variables by describing the direction and the association between them. The quantitative data collected was analyzed through the use of Statistical Package for Social Sciences (SPSS) version (23) computer software. The findings were presented in form of frequency tables, bar charts and measures of central tendencies.

The analytical model of the direct relationship between rights of shareholders and listed firms performance;

$\mathrm{Y}=\beta_{0}+\beta_{1} \mathrm{X}_{1}$ ..i

$Y=$ Firm Performance (performance of listed firms)

$\mathrm{X}_{1}=$ Rights of shareholders

$\beta_{0}=$ Constant

$\beta_{\mathrm{i}}=$ Regression coefficients 
$\varepsilon=$ Error term, was also carried out.

The study was premised on the assumption that the rights of the shareholders would explain the performance of the firm.

The Gaussian distribution was used to determine how well the data is distributed. Lapan et al. (2012) observe that in order to fit a linear model, the dependent variable has to be normally distributed. Two tests were used to confirm normality in this study; Q-Q plots and the Kolmogorov-Smirnov (KS) tests. The hypotheses:

$H_{0}:$ The dependent variable is not normally distributed;

$H_{1}$ : The dependent variable is normally distributed; were considered in testing whether the dependent variable was normally distributed. We rejected the null hypothesis as $\mathrm{P}$ value was less than 0.05 (significance level) in favor of the alternative hypothesis.

The research conducted heteroscedasticity test using Breusch-Pagan/Cook-Weisberg test to determine the existence of uniformity in dispersion of errors from regression line. A null hypothesis $\left(\mathrm{H}_{0}\right)$ was formulated that the error variance is not heteroscedastic while the alternative hypothesis $\left(\mathrm{H}_{1}\right)$ was that the error variance is heteroscedastic.

\subsection{Results}

A total of 56 questionnaires translating to $93.33 \%$ response rate were properly filled and returned by the respondents. Mugenda and Mugenda (2003) and Kothari (2004) maintain that a response rate of above 50\% is adequate for a descriptive study. See Table 2.

Table 2: Response Rate

\begin{tabular}{|l|c|c|}
\hline Response & Frequency & Percentages \\
\hline Returned & 56 & 93.4 \\
\hline Unreturned & 4 & 6.6 \\
\hline Total & $\mathbf{6 0}$ & $\mathbf{1 0 0 . 0}$ \\
\hline
\end{tabular}

Source: Field Research 2017

\subsection{Reliability Analysis and Validity Tests}

The study utilized Cronbach's alpha to test the reliability of the measures in the survey questionnaire (Cronbach, 1951) using questionnaires duly filled by 6 arbitrarily chosen respondents to ensure that it was significant and powerful. The respondents were excluded from the final study sample so as to control for response biasness. Table 3 below shows that the Cronbach alpha for the rights of shareholders and firm performance was above the threshold of 0.7 , meaning that the questionnaire was reliable.

Table 3: Reliability coefficient of variables

\begin{tabular}{|l|l|l|l|l|}
\hline Number & Variable & Cronbach's Alpha & No. of Items & Comment \\
\hline 1. & Rights of Shareholders & 0.776 & 10 & Reliable \\
\hline 2. & Firm Performance & 0.923 & 17 & Reliable \\
\hline
\end{tabular}

Source: Field Research 2017

The research established content validity - face validity, content validity and construct validity - prior to theoretical testing (Hair et al., 2007). Face validity helped the researcher in subjective evaluation of the measuring instrument and the extent to which the researcher believed the instrument was appropriate for the inquiry. The research relied on modified instruments developed in other studies as well as concepts generated from a broad range of appropriate literature. The research tested content validity by subjecting the questionnaire to a double check. Construct validity was ensured through operationalization of terms.

\subsection{Background information of the Respondents}

Table 4 shows the distribution of the firms (read respondents) from where the data was gathered. Data was obtained from all sectors; banking sector (11), Manufacturing and allied (9), Commercial service (8), Agricultural Sector (6), Automobiles and accessories (3), Construction and allied Sector (5), Energy and Petroleum (4), Insurance (6), Investment (3), and Telecommunication and Technology (1). 
Table 4: Sectors of firm's respondents

\begin{tabular}{|l|l|l|}
\hline Sector & Frequency & Percentages \\
\hline Agricultural Sector & 6 & 10.7 \\
\hline Automobiles and accessories & 3 & 5.4 \\
\hline Banking & 11 & 19.6 \\
\hline Commercial and Services & 8 & 14.3 \\
\hline Construction and allied Sector & 5 & 8.9 \\
\hline Energy and Petroleum & 4 & 7.1 \\
\hline Insurance & 6 & 10.7 \\
\hline Investment & 3 & 5.4 \\
\hline Manufacturing and allied & 9 & 16.1 \\
\hline Telecommunication and Technology & 1 & 1.8 \\
\hline Total & $\mathbf{5 6}$ & $\mathbf{1 0 0}$ \\
\hline
\end{tabular}

Source: Field Research 2017

\subsection{Exercising of Shareholders' Rights and Performance}

The study objective was to examine the relationship between exercising of shareholders' rights and performance of firms listed at the NSE. The research used sub-variables of exercising of voting rights, constructive use of AGM and ownership concentration to measure the relationship. Respondents were asked to indicate their level of agreement on the statements on exercising of shareholders' rights and firm performance. Results are presented in table 5 below. Majority respondents agreed that voting rights of shareholders were well articulated in their firm's governance policies (Mean Score $(M)=4.27$, Coefficient of Variation $(\mathrm{CV})=16.39 \%$ ). Majority respondents also agreed that their firms always held annual general meetings at least once every year, $(\mathrm{M}=4.20, \mathrm{CV}=22.43 \%)$. Majority respondents also agreed that they gave shareholders adequate time to plan and prepare for annual general meetings $(\mathrm{M}=4.05, \mathrm{CV}=25.53 \%)$. Majority respondents also agreed that they considered the opinions of shareholders to be important for setting the agenda of annual general meetings $(M=4.09, C V=38.53 \%)$. Majority respondents also agreed that shareholders were constantly encouraged to provide feedback during AGM (M=3.89, CV=40.93\%).

Similarly, majority respondents agrees that shareholders were fully allowed to exercise their voting rights $(\mathrm{M}=4.12, \mathrm{CV}=20.73 \%)$. But majority respondents disagreed that shareholders had no right to participate in the annual general meetings $(\mathrm{M}=2.37, \mathrm{CV}=27.38 \%)$. Majority respondents also agreed that shareholders have a right to appoint directors $(\mathrm{M}=4.56, \mathrm{CV}=32.27 \%)$. Finally, majority respondents agreed that shareholders have a right to receive copies of financial statements $(\mathrm{M}=3.77, \mathrm{CV}=38.51)$. On the overall the exercising of shareholders' rights had a composite index of 3.69 and $\mathrm{CV}=45.80 \%$ meaning that majority of the respondents indicated that their firms complied with shareholders exercising their rights.

The study is consistent with the findings Iliev et al. (2012) who found out that majority of the firms that they sampled across 42 countries had well-articulated policies on the voting rights of shareholders. These findings are also consistent with a study by Isik and Syokan (2013) who empirically explored the impact of large shareholders on firm performance measured by ROA and Tobin's Q. Empirical findings based on panel data analysis suggested that large shareholders had a significant positive effect on performance of a firm.

Table 5: Mean Scores and Standard Deviations for Exercising of Shareholders' Rights

\begin{tabular}{|c|c|c|c|}
\hline Statements & Mean & Std. Dev & $\mathbf{C V}$ \\
\hline $\begin{array}{l}\text { a. Voting rights of shareholders are well articulated in my firm's governance } \\
\text { policies }\end{array}$ & 4.27 & 0.70 & $16.39 \%$ \\
\hline b. Annual General Meetings are always held at least once a year & 4.20 & 0.94 & $22.43 \%$ \\
\hline c. There is a clear and efficient communication on annual general meetings & 3.73 & 1.42 & $38.10 \%$ \\
\hline $\begin{array}{l}\text { d. Shareholders are given adequate time to plan and prepare for annual general } \\
\text { meeting }\end{array}$ & 4.05 & 1.03 & $25.53 \%$ \\
\hline $\begin{array}{l}\text { e. The opinions of shareholders are considered important for annual general } \\
\text { meeting agenda }\end{array}$ & 4.09 & 1.58 & $38.53 \%$ \\
\hline
\end{tabular}




\begin{tabular}{|c|c|c|c|}
\hline f. Stakeholders are constantly encouraged to provide feedback at AGMs & 3.89 & 1.59 & $40.93 \%$ \\
\hline g. Shareholders are fully allowed to exercise their voting rights & 4.12 & 0.85 & $20.73 \%$ \\
\hline h. Shareholders have no right to participate in the annual general meetings & 2.37 & 1.10 & $27.38 \%$ \\
\hline i. Shareholders have a right to appoint directors & 4.56 & 1.21 & $32.27 \%$ \\
\hline j. $\quad$ Shareholders have a right to receive copies of financial statements & 3.77 & 1.45 & $38.51 \%$ \\
\hline Composite Index & 3.69 & 1.69 & $\mathbf{4 5 . 8 0 \%}$ \\
\hline
\end{tabular}

\section{Source: Field Research 2017}

\subsection{Factor Analysis}

Factor analysis was used to summarize data to a manageable level without losing any important information in order to make it easy to test hypothesis (Field, 2009; Tabachnick \& Fidell, 2007). Kaiser (1974) recommends that research should accept factor loading values greater than 0.4. According to him, values between 0.5 and 0.7 are mediocre, values between 0.7 and 0.8 are good, values between 0.8 and 0.9 are great, and values above 0.9 are superb. The study settled for sub variables that had values of 0.4 and above and dropped the rest. A similar threshold was used by Shale (2014) and Mwau, Oloko and Muturi (2016).

Table 6 below shows the factor loadings of the set of sub variables of the objective. All the sub variables with values of more than 0.4 were accepted. The Kaiser-Mayor-Olkin measures of sampling adequacy in table 6 (b) shows the value of test statistic of 0.590 which is a high partial correlation meaning factor analysis was appropriate.

Table 6: Shareholders' Rights Factor Loading

\begin{tabular}{|c|c|}
\hline \multicolumn{1}{|c|}{ Statements } & Factor Loading \\
\hline a. $\quad$ Voting rights of shareholders are well articulated in my firm's governance policies & 0.814 \\
\hline b. $\quad$ Annual General Meetings are always held at least once a year & 0.665 \\
\hline c. $\quad$ There is a clear and efficient communication on annual general meetings & 0.528 \\
\hline d. $\quad$ Shareholders are given adequate time to plan and prepare for annual general meeting & 0.780 \\
\hline e. $\quad$ The opinions of shareholders are considered important for annual general meeting agenda & 0.762 \\
\hline f. $\quad$ Stakeholders are constantly encouraged to provide feedback at AGMs & 0.831 \\
\hline g. $\quad$ Shareholders are fully allowed to exercise their voting rights & 0.762 \\
\hline h. $\quad$ Shareholders have no right to participate in the annual general meetings & 0.679 \\
\hline i. $\quad$ Shareholders have a right to appoint directors & 0.768 \\
\hline j. $\quad$ Shareholders have a right to receive copies of financial statements & 0.763 \\
\hline
\end{tabular}

Source: Field Research 2017

Table 6 (b) KMO and Bartlett's Results

\begin{tabular}{|l|l|r|}
\hline \multicolumn{2}{|c|}{ KMO and Bartlett's Test } & \\
\hline Kaiser-Meyer-Olkin Measure of Sampling Adequacy. & .590 \\
\hline Bartlett's Test of Sphericity & Approx. Chi-Square & 322.971 \\
\cline { 2 - 3 } & Df & 45 \\
\cline { 2 - 3 } & Sig. & .000 \\
\hline
\end{tabular}

\section{Source: Field Research 2017}

Table 7 shows all the factor loadings of all the sub variables of the dependent variable, namely firm performance. All the sub variables had factor loading values more than 0.4 and therefore accepted. The 
Kaiser-Mayor-Olkin measures of sampling adequacy in table 7 (b) show the value of test statistic of 0.506 which is a high partial correlation meaning that factor analysis was appropriate.

Table 7: Firm Performance Factor Loading

\begin{tabular}{|c|c|}
\hline Statements & Factor Loading \\
\hline a. $\quad$ Gross revenue generated by the company increased & 0.729 \\
\hline b. $\quad$ Net profit of the company increased & 0.800 \\
\hline c. $\quad$ Cost base of the company decreased & 0.921 \\
\hline d. $\quad$ Attracted many customers. & 0.891 \\
\hline e. $\quad$ Had satisfied customers. & 0.606 \\
\hline f. $\quad$ Retained customers. & 0.761 \\
\hline g. $\quad$ Resolved customer complaints. & 0.866 \\
\hline h. $\quad$ Market share has expanded. & 0.748 \\
\hline i. $\quad$ Offered products /services of high quality. & 0.907 \\
\hline j. $\quad$ Increased operational efficiency. & 0.701 \\
\hline k. $\quad$ Offered after sales service to our customers. & 0.742 \\
\hline l. $\quad$ Company introduced new products. & 0.688 \\
\hline m. $\quad$ Developed new products. & 0.841 \\
\hline n. $\quad$ Entered new markets. & 0.772 \\
\hline o. $\quad$ Developed management competency. & 0.796 \\
\hline p. $\quad$ Enhanced the ability of managers to perform their work. & 0.681 \\
\hline q. $\quad$ Enhanced research and development. & \\
\hline Source & Field Research 2017 \\
\hline
\end{tabular}

Source: Field Research 2017

Table 7 (b) KMO and Bartlett's Results

\begin{tabular}{|l|l|r|}
\hline \multicolumn{3}{|c|}{ KMO and Bartlett's Test } \\
\hline Kaiser-Meyer-Olkin Measure of Sampling Adequacy. & \\
\hline Bartlett's Test of Sphericity & Approx. Chi-Square & .506 \\
\cline { 2 - 3 } & Df & 408.367 \\
\cline { 2 - 3 } & Sig. & 136 \\
\hline
\end{tabular}

\section{Source: Field Research 2017}

\subsubsection{Diagnostic Tests}

\section{Test for Normality}

The research used Kolmogorov-Smirnov test and Q-Q Plots to perform preliminary analysis to assess if the data fits a normal distribution. The results are shown in table 8 below. All data with non-significant results ( $>$ >0.05) score fit a normal distribution (Tabachnick \& Fidell, 2007), which was the case in the study. Hence, the data was suitable for analysis using correlation and regression. The Q-Q plot of shareholders rights also shows that the data was normally distributed; see Fig. 1 below.

Table 8: Results of Kolmogorov-Smirnov Test for Normality

\begin{tabular}{|l|c|c|c|}
\hline Variable & K-S Test Statistic & df & Sig. \\
\hline Firm Performance & 2.191 & 56 & 0.073 \\
\hline Shareholders Rights & 2.167 & 56 & 0.064 \\
\hline
\end{tabular}

Source: Field Research 2017 


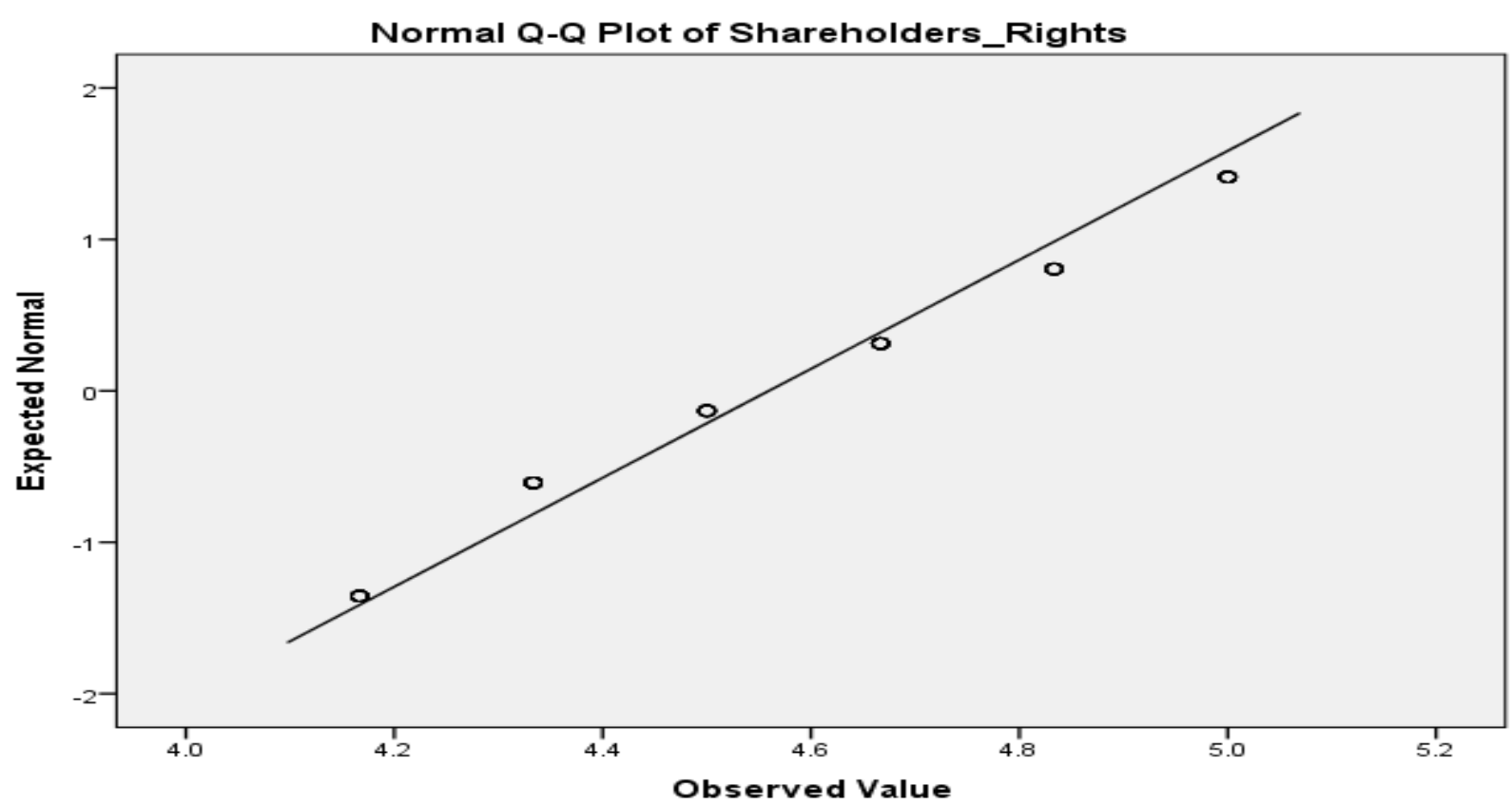

\section{Source: Field Research 2017}

\section{Test for Heteroscedasticity}

The data for this research is obtained from a cross-section of firms and it was therefore prudent to check for the existence of heteroscedasticity. The researcher carried out Breusch-Pagan/Cook-Weisberg test to confirm if the error variance was not constant. For the purposes of applying the Breusch-Pagan/CookWeisberg test, a null hypothesis $\left(\mathrm{H}_{0}\right)$ of this was formulated that the error variance is not heteroscedastic while the alternative hypothesis $\left(\mathrm{H}_{1}\right)$ was that the error variance is heteroscedastic. The BreuschPagan/Cook-Weisberg test models the error variance as $\sigma 2 \mathrm{i}=\sigma 2 \mathrm{~h}\left(\mathrm{z}^{\prime} \mathrm{i} \beta\right)$ where $\mathrm{zi}$ is a vector of the independent variables. It tests $\mathrm{H}_{0}: \beta=0$ versus $\mathrm{H}_{1}: \beta \neq 0$. The results of the Breusch-Pagan/Cook-Weisberg test are shown in table 9 below.

Table 9: Results of Breusch-Pagan / Cook-Weisberg Test for Heteroscedasticity

Breusch-Pagan / Cook-Weisberg test for heteroscedasticity

chi2(1) = 2.47

Prob $>$ chi $2=0.1160$

Source: Field Research 2017

The results in table 9 above indicate that the $\mathrm{p}$ value is greater than $0.05(\mathrm{p}=0.1160)$ thereby supporting the null hypothesis set up for this test. Hence the variables in this study did not suffer from heteroscedasticity.

\section{Regression Analysis}

The study further carried out regression analysis to establish the statistical significance on the relationship between the rights of shareholders $\left(\mathrm{X}_{1}\right)$, on the performance of listed firms (Y). The regression model of $\mathrm{X}_{1}$ and $\mathrm{Y}$ was significant $(\mathrm{F}(1,54)=11.898$, p-value $=0.001)$, meaning that the shareholders exercising their rights is a valid predictor in the model as shown in Table 10(a) below. The coefficient of determination $\mathrm{R}^{2}$ of 0.181 indicates that $18.1 \%$ of firm performance can be explained by the dimension of shareholders exercising their rights in corporate governance. The adjusted $\mathrm{R}^{2}$ explained 0.165 or $16.5 \%$, meaning that the rest can be explained by other factors not present in the model. The $\mathrm{R}$ of 0.181 implies a weak positive correlation between shareholders exercising their rights and firm performance. The standard error of 0.301 shows the deviation from the line of best fit shown in Table 10 (b). The study hypothesized $\mathbf{H}_{\mathbf{0 1}}$ : There is no significant relationship between shareholders exercising their rights and the performance of listed firms. Results show there is positive relationship between shareholders exercising their rights and performance of 
listed firms in Kenya. $\left(\beta_{1}=0.503, t=3.449\right.$, $\mathrm{p}$-value $\left.=0.001\right)$. To test the relationship the Regression Model fitted was $\mathbf{Y}=\boldsymbol{\beta}_{\mathbf{0}}+\boldsymbol{\beta}_{\mathbf{1}} \mathbf{X}_{\mathbf{1}}+\boldsymbol{\varepsilon}$. The null hypothesis $\left(\mathrm{H}_{01}\right)$ : There is no significant relationship between shareholders exercising their rights and the performance of listed firms or $\left(\mathrm{H}_{01}: \beta_{1}=0\right)$ is therefore rejected. $\left(\beta_{1}=0.503, \mathrm{t}=3.449, \mathrm{p}\right.$-value $\left.=0.001\right)$ and conclude that shareholders exercising their rights $\left(\mathrm{X}_{1}\right)$ significantly influences firm performance $(\mathrm{Y})$. The Model equation is: $\mathrm{Y}=2.127+0.503 \mathrm{X}_{1}$.

The beta coefficient for shareholders exercising their rights was significant $\left(\beta_{1}=0.503, t=3.449, p\right.$-value $=$ $0.001)$, meaning that 1 unit increase in shareholders exercising their rights in corporate governance increases the firm performance index by 0.503 as shown in table 10 (c).

Table 10: Regression Analysis for exercising of shareholders' rights and performance

\begin{tabular}{|c|c|c|c|c|c|c|c|c|c|c|c|c|}
\hline \multicolumn{13}{|c|}{ (a) Model Summary } \\
\hline \multirow{2}{*}{$\begin{array}{l}\text { Mode } \\
1\end{array}$} & \multirow[t]{2}{*}{$\mathrm{R}$} & \multirow{2}{*}{$\begin{array}{l}\mathrm{R} \\
\text { Squar } \\
\mathrm{e}\end{array}$} & \multirow{2}{*}{\multicolumn{2}{|c|}{$\begin{array}{l}\text { Adjusted } \\
\text { R Square }\end{array}$}} & \multirow{2}{*}{\multicolumn{2}{|c|}{$\begin{array}{l}\text { Std. Error of } \\
\text { the Estimate }\end{array}$}} & \multicolumn{6}{|c|}{ Change Statistics } \\
\hline & & & & & & & $\begin{array}{l}\mathrm{R} \text { Square } \\
\text { Change }\end{array}$ & $\begin{array}{l}\mathrm{F} \\
\text { Chang } \\
\mathrm{e}\end{array}$ & df1 & & df2 & $\begin{array}{l}\text { Sig. F } \\
\text { Change }\end{array}$ \\
\hline 1 & $\begin{array}{l}.4 \\
25\end{array}$ & .181 & .16 & & .300 & 6412 & .181 & 11.898 & 1 & & 54 & .001 \\
\hline \multicolumn{13}{|c|}{ (b) ANOVA } \\
\hline \multicolumn{4}{|l|}{ Model } & \multicolumn{2}{|c|}{$\begin{array}{l}\text { Sum of } \\
\text { Squares }\end{array}$} & Df & $\begin{array}{l}\text { Mean } \\
\text { Square }\end{array}$ & $\mathrm{F}$ & & \multicolumn{3}{|c|}{ Sig. } \\
\hline \multirow[t]{3}{*}{1} & \multicolumn{3}{|c|}{ Regression } & \multicolumn{2}{|c|}{1.075} & 1 & 1.075 & 11.898 & & \multicolumn{3}{|c|}{.001} \\
\hline & \multicolumn{2}{|c|}{ Residual } & \multicolumn{3}{|c|}{4.881} & 54 & .090 & & & & & \\
\hline & \multicolumn{2}{|c|}{ Total } & \multicolumn{3}{|c|}{5.956} & 55 & & & & & & \\
\hline \multicolumn{13}{|c|}{ (c) Coefficients } \\
\hline \multirow{2}{*}{\multicolumn{3}{|c|}{ Model }} & \multicolumn{3}{|c|}{$\begin{array}{l}\text { Unstandardized } \\
\text { Coefficients }\end{array}$} & \multicolumn{2}{|c|}{$\begin{array}{l}\text { Standardized } \\
\text { Coefficients }\end{array}$} & \multirow[t]{2}{*}{$\mathrm{t}$} & \multirow{2}{*}{\multicolumn{2}{|c|}{ Sig. }} & \multicolumn{2}{|c|}{$\begin{array}{l}\text { Collinearity } \\
\text { Statistics }\end{array}$} \\
\hline & & & $\mathrm{B}$ & \multicolumn{2}{|c|}{ Std. Error } & Beta & & & & & $\begin{array}{l}\text { Toleranc } \\
\mathrm{e}\end{array}$ & VIF \\
\hline \multirow[t]{2}{*}{1} & \multicolumn{2}{|c|}{ (Constant) } & 2.127 & \multicolumn{2}{|c|}{.666} & & & 3.192 & .002 & & & \\
\hline & $\mathrm{X} 1$ & & .503 & .14 & & .425 & & 3.449 & .00 & & 1.000 & $\begin{array}{l}1.00 \\
0\end{array}$ \\
\hline
\end{tabular}

\section{Source: Field Research 2017}

Results of a simple linear regression to establish the significance and the contribution of exercise voting rights, constructive use of AGM and ownership concentration and firm performance, by ordering $\mathrm{R}^{2}$ are as shown in table 11. Ownership concentration exhibited the highest contribution with $\mathrm{R}^{2}$ of $12.4 \%$, followed by constructive use of AGM with $\mathrm{R}^{2}$ of $9.6 \%$ and lastly exercising of voting rights with $\mathrm{R}^{2}$ of $7.7 \%$.

Table 11: Exercising of Shareholders' Rights

\begin{tabular}{|l|l|c|c|c|}
\hline Main Variable & Sub Variable & Beta Coefficients & $\mathbf{R}^{\mathbf{2}}$ & \multicolumn{1}{|c|}{ Sig } \\
\hline Exercising of Shareholders' Rights & Exercise of voting rights & 0.112 & 0.077 & 0.008 \\
\hline & Constructive use of AGM & 0.016 & 0.096 & 0.049 \\
\hline & Ownership concentration & 0.102 & 0.124 & 0.033 \\
\hline
\end{tabular}

Source: Field Research 2017

\section{Summary}

The objective of the research was to examine the relationship between exercising of shareholders' rights and performance of firms listed at the NSE. We hypothesized that Ho: Shareholders exercising their rights has no significant relationship with performance of firms listed at the NSE. The $\mathrm{p}<0.001$ and hence the null hypothesis was rejected; therefore, shareholders exercising their rights has significant relationship with performance of firms listed at the NSE.

\section{Conclusions}

The objective of this study was to examine the relationship between exercising of shareholders' rights and the performance of firms listed at the Nairobi Securities Exchange (NSE). Regression results showed that exercising of shareholders' rights has a positive significant relationship with 18.1 percent variation in 
performance of firms listed at the NSE. In particular the study found that ownership concentration plays the highest role, followed by constructive use of annual general meeting, with shareholders exercising their voting rights playing the least role in explaining the relationship between shareholders' rights and firm performance. From the foregoing, it can be concluded that an improvement in exercising shareholders rights will lead to a positive improvement in performance of firms listed at the NSE.

Further, this study adds to provisions of stewardship theory that in the quest to do well, the steward, is intrinsically obliged to ensure that all categories of a firm's stakeholders get an opportunity to exercise their rights. The steward must ensure that the shareholders exercise their rights with a view to enhancing the performance of the firm. The findings agree with shareholder value theory that the firm becomes a web of implicit and explicit contacts but with the shareholder having a primacy over other stakeholders (Margolis \& Walsh, 2003). It depicts the board and the management of a firm as having fiduciary duty of maximizing shareholder value.

\section{References}

[1] Agarwal, A. \& Knoeber, C. (1996). Firm Performance and Mechanisms to Control Agency Problems between Managers and Shareholders. Journal of Financial and Quantitative Analysis, 31(3), 377397.

[2] Bainbrigde, W. S. (2006). Transformative Concepts in Scientific Convergence. Annals of the New York Academy of Sciences, 1093, 24-45. doi:10.1196/annals.1382.003

[3] Balta, M. (2008). The impact of Business Environment and Boards of Directors on Strategic Decision-Making: A Case Study of Greek Listed Companies. Unpublished PhD Thesis, Brunei Business School.

[4] Bebchuk, L. (2006). The Case of Increasing Shareholders Power. Harvard Law Review, 833.

[5] Biwott, R. K. (2011). The Relationship between Working Capital Management Practices and Profitability of Companies Quoted at the Nairobi Stock Exchange. Unpublished Project, University of Nairobi.

[6] Carton, R. B. \& Hofer, C. W. (2006). Measuring Organizational Performance: Metrics for Entrepreneurship and Strategic Management Research. Cheltenham: Edward Elgar Publishing Limited.

[7] CMA (2013). Report of the Capital Markets Authority 2013. Government Printers. Nairobi.

[8] CMA (2015). Report of the Capital Markets Authority 2015. Government Printers. Nairobi.

[9] Core, J. E. \& D. F. Larcker. (2002). Performance Consequences of Mandatory Increases in Executive Stock Ownership. Journal of Financial Economics, 64(3), 317-340.

[10] Davis, J., Schoorman, F. \& Donaldson, L. (1997). Toward a Stewardship Theory of Management. Academy of Management Review, 22(20-47), 371-382.

[11] Demsetz, H. \& Lehn, K. (1985). The Structure of Corporate Ownership: Causes and Consequences. Journal of Political Economy, 93, 1155-1177.

[12] Donaldson, L. \& Davis, J. (1991). Stewardship Theory or Agency Theory: CEO Governance and Shareholder Returns. Australian Journal of Management, 16(1).

[13] Gakeri, J. K. (2013). Enhancing Kenya's Securities Markets through Corporate Governance: Challenges and Opportunities. International Journal of Humanities and Social Science, 3(6), 1-24. Retrieved November 12, 2016, from http://www.ijhssnet.com/journals

[14] Gardiner, J. J. (2006). "Transactional, Transformational, and Transcendent Leadership: Metaphors Mapping The Evolution Of The Theory And Practice Of Governance,". Kravis Leadership Institute Leadership Review, 6, 62-76.

[15] Gonenc, H. \& Aybar, C. (2006). Financial Crisis and Firm Performance: Empirical evidence from Turkey. Corporate Governance: An International Review, 14, 297-311. doi:10.1111/j.14678683.2006.00508.x

[16] Haller, A. (2003). Accounting in Germany (2 ed.). Thomson. Retrieved November 14, 2016

[17] Irungu, S. (2007). The effect of Top Teams on the performance of publicly quoted companies in Kenya. Unpublished Phd Thesis, University of Nairobi, Kenya. 
[18] Isik, O. \& Soykan, M. E. (2013). Large Shareholders and Firm Performance: Evidence From Turkey. European Scientific Journal, 9, 23-37.

[19] Kithii, J. (2008). The Relationship between Working Capital Management and Profitability of Companies listed on the Nairobi Stock Exchange. Unpublished Project, Nairobi University.

[20] Kobuthi, E., K'Obonyo, P. \& Ogutu, M. (2018). Corporate Governance and Performance of Firms Listed on the Nairobi Securities Exchange. International Journal of Scientific Research and Management (IJSRM) Vol. 6, Issue1 (2018).

[21] Kothari, C. (2010). Research Methodology: Methods \& Techniques. New Age International Publishers.

[22] Lapan, S., Quartaroli, M. \& Riemer, F. (2012). Qualitative Research: An Introduction to Methods and Designs. San Francisco: Jossey-Bass.

[23] Mahboob, A. (2015). "Financial analysis of commercial banks". International Journal of Research in Commerce, IT and Management, 5(3).

[24] Margolis, J. \& Walsh, J. (2003). Misery loves companies: rethinking social initiatives by business. Administrative Science Quarterly, 48(2), 268-306.

[25] Maria Maher, M. \& Andersson, T. (1999). Corporate Governance: Effects on Firm Performance and Economic Growth. Organisation for Economic Co-Operation and Development

[26] Marinova, D. (2004). Actualizing innovation effort: the impact of market knowledge diffusion in a dynamic system of competition. Journal of Marketing, 68(3), 1-20.

[27] McConnell, J. J. \& Servaes, H. (1990). Equity ownership and the two faces of debt. Journal of Financial Economics, 39, 131-157.

[28] Miles, L. (2006). The Application of Anglo-American Corporate Practices in Societies Influenced by Confucian Values. Business and Society Review, 111(3).

[29] Miwa, Y. (2006). Corporate Governance in Japan-From the Viewpoints of Management, Accounting and Market. Tokyo: Springer. Retrieved November 14, 2016

[30] Morck, R., Shelfer, A. \& Vishny, R. (1988). Management Ownership and Market Valuation: Am empircal Analysis. Journal of Economoics, 20, 293-315.

[31] Mugenda, O. \& Mugenda, A. (2003). Research Methods Quantitative and Qualitative Approaches. Nairobi: Acts Press.

[32] Mukabwa, J. (2016). A Brief History of Corporate Governance. Corporate Governance in Kenya.

[33] Mwau, P., Oloko M. \& Muturi, W. (2016). The Influence of Market Development Strategy on Performance of Firms within the Insurance Industry in Kenya. International Journal of Advanced Engineering and Management Research, Vol. 1(Issue 2), 1-40.

[34] Nderu, M. (2013). Influence of Survival Strategies on the Organizational Performance of Kenya Airways. International Journal of Social Sciences and Entrepreneurship, 1(2), 496-512.

[35] Ngugi, R. W. (2003). Development of the Nairobi Stock Exchange: Historical Perspective. Discussion Paper, KIPPRA.

[36] NSE (2013). Report of the Nairobi Securities Exchange 2013. Government Printers. Nairobi.

[37] OECD. (1999). Principles of Corporate Governance. Organization for Economic Corporation

[38] Omondi, D. (2015, October 1st ). Mumias Sugar Company doubles full year loss to Sh6 billion on low revenues. Standard Digital.

[39] Onder, Z. (2003). Ownership Concentration and Firm Performance : Evidence from Turkish Firms: t. METU studies in Developmen, 30(2), 181-203.

[40] Ongore, V. (2008). The effects of ownership structure, board effectiveness and managerial discretion on performance of listed companies in Kenya. Unpublished Phd Thesis, University of Nairobi, Kenya.

[41] Organization for Economic Co-operation and Development. (2009). Corporate Governance and financial crisis: Key findings and main messages. Paris OECD.

[42] Orlitzky, M., Schmidt, F., \& Rynes, S. (2003). Corporate social and financial performance: A metaanalysis. Organizational studies, 24(3), 403-441.

[43] Osborne, J., \& Walters, E. (2002). Four assumptions of multiple regression that researchers should always test. Practical Assessment, Research \& Evaluation, 8(2). Retrieved from http://PAREonline.net/getvn.asp?v=8\&n=2 
[44] Outa, E. (2013). Earnings Management \& Corporate Governance Disclosure: Empirical Evidence from East Africa. AIDEA Conference.

[45] Shale, I. (2014). Role of E-Procurement Strategy on the Performance of State Corporations in Kenya. Nairobi: Phd Thesis.

[46] Strine, L. (2006). Towards A true corporate Republic: A traditionalist response Bebchucks solution for improving Corporate America.

[47] Tabachnik, B. \& Fidell, L. (2013). Using Multivariate Statistics (6th ed.). Boston Pearson Publishers.

[48] Talbot, C. (2010). Theories of Performance: Organizational Improvement. Oxford: Oxford University Press.

[49] Taylor, A. \& Taylor, M. (2013). "Factors Influencing Effective Implementation of Performance Measurement Systems in a Small and Medium-sized Enterprises and Large Firms: A Perspective from Contingency Theory". International Journal of Production Research, 52(3), 847-866.

[50] Tipuric, D. (2008). Korporativno upravljanje. Sinergija, 9536895-07-02. Zagreb.

[51] Velasco, J. (2004). Structural Bias and the need for Substantive Review. Washington University Law Quarterly, 82, 821-917.

[52] Wanyama, D. \& Olweny, T. (2013). Effects of Corporate Governance on Financial Performance of Listed Insurance Firms in Kenya. Public Policy and Administration Research, 3(4).

[53] Wheeler, D., Colbert, B. \& Freeman, F. (2003). Focusing On Value: Focusing On Value: Reconciling Corporate Social Responsibility, Sustainability and a Stakeholder Approach in a Network World. Journal of General Management, 28, 1-28.

[54] World Bank. (2014). Corporate Governance of State-owned Enterprises. The World Bank: Washington D.C. 